\title{
Vector-borne pathogens affecting shelter dogs in eastern Crete, Greece
}

\author{
Mathias Hofmann ${ }^{1} \cdot$ Adnan Hodžić $^{1} \cdot$ Niki Pouliou $^{2} \cdot$ Anja Joachim $^{1}$ (I)
}

Received: 4 January 2019 / Accepted: 4 March 2019 /Published online: 13 March 2019

(C) The Author(s) 2019

\begin{abstract}
Canine pathogens transmitted by blood-sucking arthropods are of significant importance for veterinary and, in some cases, human health. However, they are still underestimated and rarely investigated in many parts of the Mediterranean region, mostly due to financial reasons. Therefore, in the present paper, we investigated the occurrence of blood-associated pathogens affecting dogs in Crete, Greece. For this purpose, blood samples from 103 shelter dogs were screened for the pathogens by PCR and serological tests. Overall, samples from 43 dogs scored positive for at least one pathogen (41.8\%). In particular, antibodies to Leishmania infantum were detected in $26 \mathrm{dogs}(25.2 \%)$, and 15 and 11 animals were positive for Hepatozoon canis (14.6\%) and Mycoplasma haemocanis (10.7\%) by PCR, respectively. Co-infections were recorded in nine animals. Clinical signs indicative of infection (alterations of skin or coat or reduced body condition) were detected in 10 animals, four of which were infected with one pathogen, three with two pathogens. Based on the results obtained, dogs from Crete appear to be frequently exposed to several blood-borne pathogens, including agents of zoonotic concern. Given that some of the pathogens were reported for the first time in this area, results presented in our study should improve the awareness of the local veterinarians and of dog rescue organisations in order to reduce disease burden on stray and owned dogs and to control the spread of canine vector-borne diseases from Greece to non-endemic areas by travelling or exported infected dogs.
\end{abstract}

Keywords Arthropod-borne $\cdot$ Blood-borne $\cdot$ Shelter $\cdot$ Leishmania $\cdot$ Hepatozoon $\cdot$ Mycoplasma

\section{Introduction}

Canine vector-borne diseases (CVBD) are caused by a range of infectious agents, transmitted by blood-feeding arthropods, including ticks, mosquitoes, fleas, and phlebotomine sandflies. In addition to their veterinary importance, some of

Section Editor: Domenico Otranto

Anja Joachim

Anja.Joachim@vetmeduni.ac.at

Mathias Hofmann

mathias.hofmann1@gmx.at

Adnan Hodžić

adnan.hodzic@vetmeduni.ac.at

Niki Pouliou

androniki.pouliou@gmail.com

1 Institute of Parasitology, Department of Pathobiology, University of Veterinary Medicine Vienna, Veterinaerplatz 1, 1210 Vienna, Austria

2 Animal Medical Center, Kýprou 61, 72200 Ierapetra, Greece the pathogens are of a major zoonotic concern and may even cause severe and life-threatening diseases in humans (Otranto et al. 2009). The global distribution and unspecific clinical presentations in infected animals make the diagnosis and control of CVBD highly complex and challenging (Miró et al. 2013). Stray and free-roaming dogs are particularly at high risk of infection due to a lifestyle that involves frequent exposure to competent arthropod vectors and poor veterinary health care, and consequently they represent a permanent source of infection for the vectors and indirectly for other animals and humans (Otranto et al. 2009; Diakou et al. 2018). Expansion of CVBD and their vectors could in principle be attributed to climate changes and habitat changes, but increasing pet tourism and export of stray dogs from endemic to non- or low-endemic countries have been confirmed as an efficient route of pathogen dissemination (Menn et al. 2010; Otranto et al. 2009).

Over the past decades, an increasing number of scientific reports of CVBD in both pet and stray dogs in Europe have been published. However, data on their distribution are still not available for all endemic areas, including parts of insular 
Greece, where CVBD are assumed to be highly prevalent. A more recent study showed that up to $65 \%$ of dogs living on four islands of Greece (Santorini, Tinos, Ios, and Skiathos) were infected with vector-transmitted pathogens, and most of them have a zoonotic potential (Diakou et al. 2018). Since data from Crete, the largest Greek island, are missing, we aimed to investigate the occurrence of common bloodborne protozoa (Leishmania, Babesia, Hepatozoon), bacteria (Anaplasmataceae, hemotropic mycoplasmas), and filarioid nematodes in dogs from shelters.

\section{Material and methods}

In December 2017, four animal shelters (Fig. 1) in eastern Crete were contacted and asked to participate in this prospective study. The majority of animals were ownerless and taken to the shelters from streets, and thus were most likely not vaccinated and not treated against parasites on a regular basis. In total, 103 dogs of different breeds, sex, and age were included in the study. The animals were checked for the presence of ectoparasites and clinically examined for signs indicative of CVBD (e.g., anorexia, lethargy, pale mucous membranes, dermatological and ocular alterations, hyperthermia, or enlarged lymph nodes). Blood samples for molecular and serological analyses were taken from available dogs from the cephalic or lateral saphenous vein. Quick tests (SNAP® Leishmania and SNAP ${ }^{\circledR}$ Heartworm RT tests, IDEXX Veterinary Diagnostics, Westbrook, ME) were performed on the sampling day to detect antibodies against Leishmania infantum or antigen of the heartworm Dirofilaria immitis. Whole blood was stored at $-18{ }^{\circ} \mathrm{C}$ until used for molecular analyses. All sampling procedures were routinely performed by veterinarians on study sites, and the work was approved by local authorities. No further ethic permissions were required as no additional samples (besides the ones for routine health inspection of incoming animals) were taken for this study and the supervising veterinarian (NP) participated in the study.

DNA was extracted from $200 \mu$ l EDTA-blood with a High Pure PCR Template Preparation Kit (Roche Diagnostics GmbH, Germany) following the manufacturer's instructions. Targets and primer sequences used for molecular detection of the tested pathogens are listed in Table 1. PCR products were separated using 2\% agarose gel stained with Midori Green Advance DNA (Nippon Genetics Europe, Germany). Purification and sequencing of the amplicons were carried out by a commercial provider (LGC Genomics, Germany). Obtained nucleotide sequences were edited with BioEdit software v.7.2.5 (Hall 1999) and then checked for similarity with those available in the GenBank ${ }^{\circledR}$ database (http://www.ncbi. nlm.nih.gov/BLAST).

Fig. 1 A map of Greece showing locations of the dog shelters involved in the study

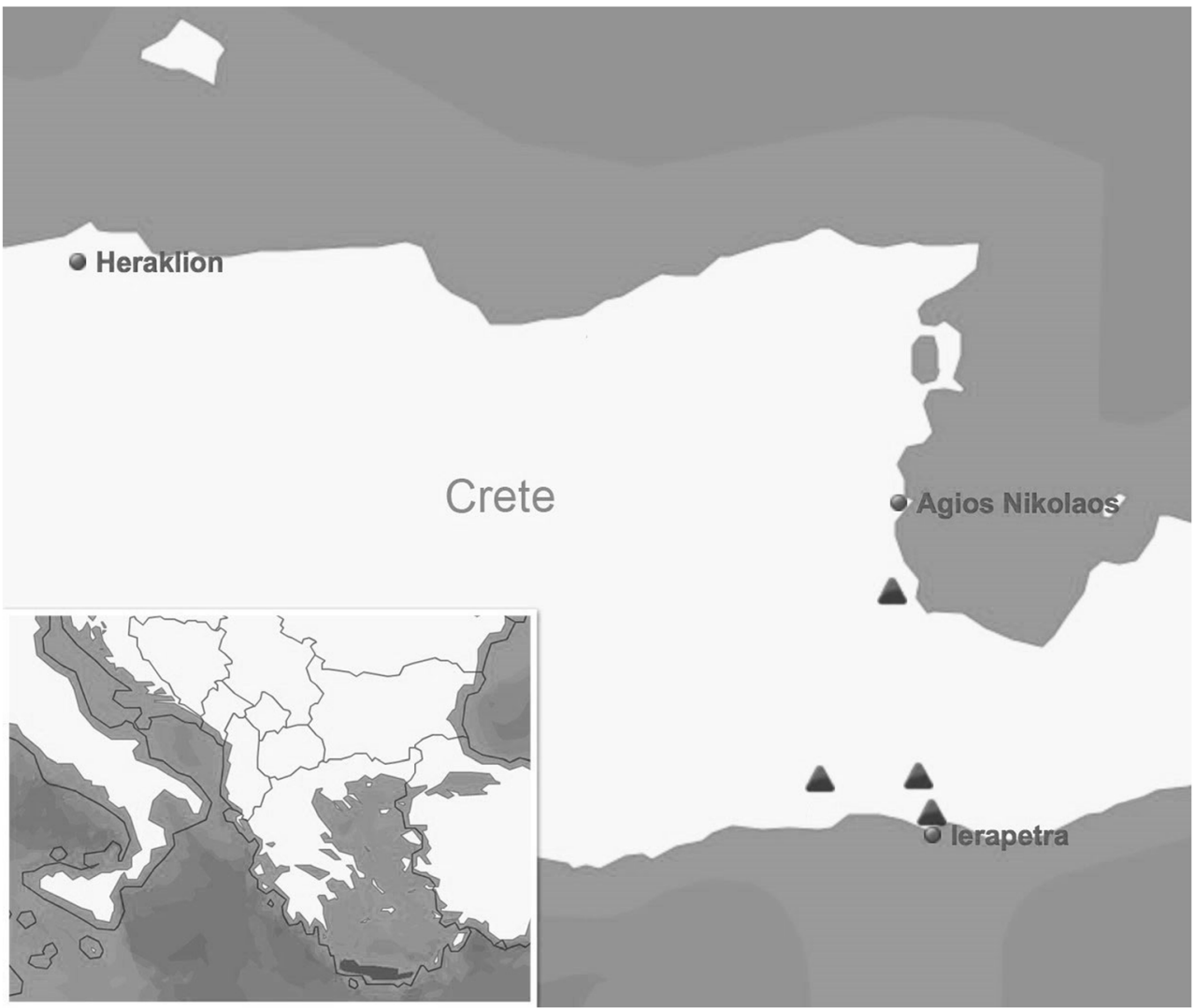


Table 1 Primer sets and protocols used for PCR amplification of blood-borne agents in dogs from Crete, Greece

\begin{tabular}{|c|c|c|c|c|}
\hline Target organism & Genetic marker & Primer sequences $\left(5^{\prime} \rightarrow 3^{\prime}\right)$ & Product size (bp) & Reference \\
\hline \multirow[t]{3}{*}{ Leishmania infantum } & kDNA & $\begin{array}{l}\text { RV1: CTTTTCTGGTCCCGCGGGTAGG } \\
\text { RV2: CCACCTGGCCTATTTTACACCA }\end{array}$ & 145 & le Fichoux et al. 1999 \\
\hline & ssu-rRNA & $\begin{array}{l}\text { Lei70L: CGCAACCTCGGTTCGGTGTG } \\
\text { Lei70R: CGCGGTGCTGGACACAGGGTA }\end{array}$ & 345 & Spanakos et al. 2002 \\
\hline & $c p b$ & $\begin{array}{l}\text { Leicpb_for: CGTGACGCCGGTGAAGAAT } \\
\text { Leicpb rev: CGTGCACTCGGCCGTCTT }\end{array}$ & 702 & Hide and Bañuls 2006 \\
\hline Babesia/Hepatozoon & 18S rRNA & $\begin{array}{l}\text { BTH-1ㄹ: CCTGAGAAACGGCTACCACATCT } \\
\text { BTH-1R: TTGCGACCATACTCCCCCCA } \\
\text { Nested } \\
\text { GF2: GTCTTGTAATTGGAATGATGG } \\
\text { GR2: CCAAAGACTTTGATTTCTCTC }\end{array}$ & $\begin{array}{l}720 / 750 \\
590 / 610\end{array}$ & Zintl et al. 2011 \\
\hline Hepatozoon spp. & 18S rRNA & $\begin{array}{l}\text { H14Hepa18SFw: GAAATAACAATACAAGGC } \\
\text { AGTAAAATGCT } \\
\text { H14Hepa18SRv: GTGCTGAAGGAGTCGTTTAT } \\
\text { AAAGA }\end{array}$ & 620 & Hodžić et al. 2015 \\
\hline Anaplasmataceae & 16S rRNA & $\begin{array}{l}\text { EHR16SD: GGTACCYACAGAAGAAGTCC } \\
\text { EHR16SR: TAGCACTCATCGTTTACAGC }\end{array}$ & 345 & Brown et al. 2001 \\
\hline Hemotropic mycoplasmas & 16S rRNA & $\begin{array}{l}\text { HBT-F: TACGGCCCATATTCCTACG } \\
\text { HBT-R: TGCTCCACCACTTGTTCA }\end{array}$ & 600 & $\begin{array}{l}\text { Criado-Fornelio } \\
\text { et al. } 2003\end{array}$ \\
\hline Filarioid nematodes & $\mathrm{COI}$ & $\begin{array}{l}\text { H14FilaCOIFw: GCCTATTTTGATTGGTGGTTTTGG } \\
\text { H14FilaCOIRv: AGCAATAATCATAGTAGCAGCACTAA }\end{array}$ & 724 & Hodžić et al. 2015 \\
\hline
\end{tabular}

\section{Results}

Of the 103 dogs sampled (50 male and 53 female, 94 estimated to be 1 year or older and nine less than 1 year), 29 originated from a shelter in the area of Kefala, 28 are from a shelter located in the area of Nea Anatoli, 40 samples were collected from a shelter in the area of Agios Nikolaos, and six dogs originated from the town of Ierapetra (Fig. 1).

Overall, 43 dogs were positive for at least one pathogen, which corresponds to a prevalence of $41.7 \%$ (95\% confidence interval $\left[\mathrm{CI}_{95}\right]$ 32.7-51.4\%) (Fig. 2). Mixed infections with two pathogens were observed in nine dogs $\left(8.7 \%\right.$; $\mathrm{CI}_{95} 4.7-$ $18.8 \%$ ). In particular, sera from 26 dogs tested positive for L. infantum antibodies (25.2\%; $\mathrm{CI}_{95}$ 17.9-34.4\%) and five of these individuals displayed clinical signs which could be related to the infection (Fig. 2). However, no dog was positive in the PCR assays targeting Leishmania kinetoplast DNA (kDNA), small subunit ribosomal RNA (ssu-rRNA), and cysteine-proteinase $\mathrm{B}(c p b)$ genes.

Hepatozoon canis was detected in the blood of 15 dogs (14.6\%; $\mathrm{CI}_{95}$ 9.0-22.7\%) examined by PCR (18S rRNA gene). Sequence analyses revealed two different genetic variants; 14 sequences were identical to each other and displayed $100 \%$ homology to $H$. canis genotypes (GenBank®, e.g., KC138532) and one showed a 99\% identity to, e.g., KX712126 genotype. One dog infected with $H$. canis had a poor body condition. Six dogs additionally had anti-Leishmania antibodies detected in the SNAP® test from which two individuals showed clinical disease manifestations (Fig. 2).
PCR assay targeting the $16 S$ rRNA gene of hemotropic mycoplasmas delivered positive results in 11 samples

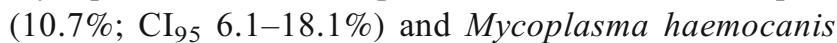
(100\% homology to M. haemocanis sequence KY117659) was confirmed by sequencing with complete homology for all obtained sequences. One of the Mycoplasma-infected dogs showed alopecia, and one dog co-infected with Leishmania showed alterations of the skin and coat and a reduced body condition (Fig. 2). Other pathogens tested for were not confirmed by using molecular and/or serological tools.

No ectoparasites were observed on the animals.

\section{Discussion}

This study was performed to investigate the occurrence of important canine vector-borne pathogens on the island of Crete, where no data are available on these infections so far. Despite the small study population, three out of the six pathogens tested for could be detected, and the study revealed a high number of positive animals overall, and, to the best of our knowledge, reports the occurrence of $H$. canis and M. haemocanis for the first time on this Greek island.

In total, $25.2 \%$ of the dogs were positive for $L$. infantum antibodies, which is in accordance with the national mean seroprevalence previously reported in owned and stray dogs (Dujardin et al. 2008; Ntais et al. 2013). Leishmania DNA, however, was not detected by PCRs. This could be explained by the low sensitivity of PCR performed using peripheral blood as substrate, compared to spleen or lymph nodes 


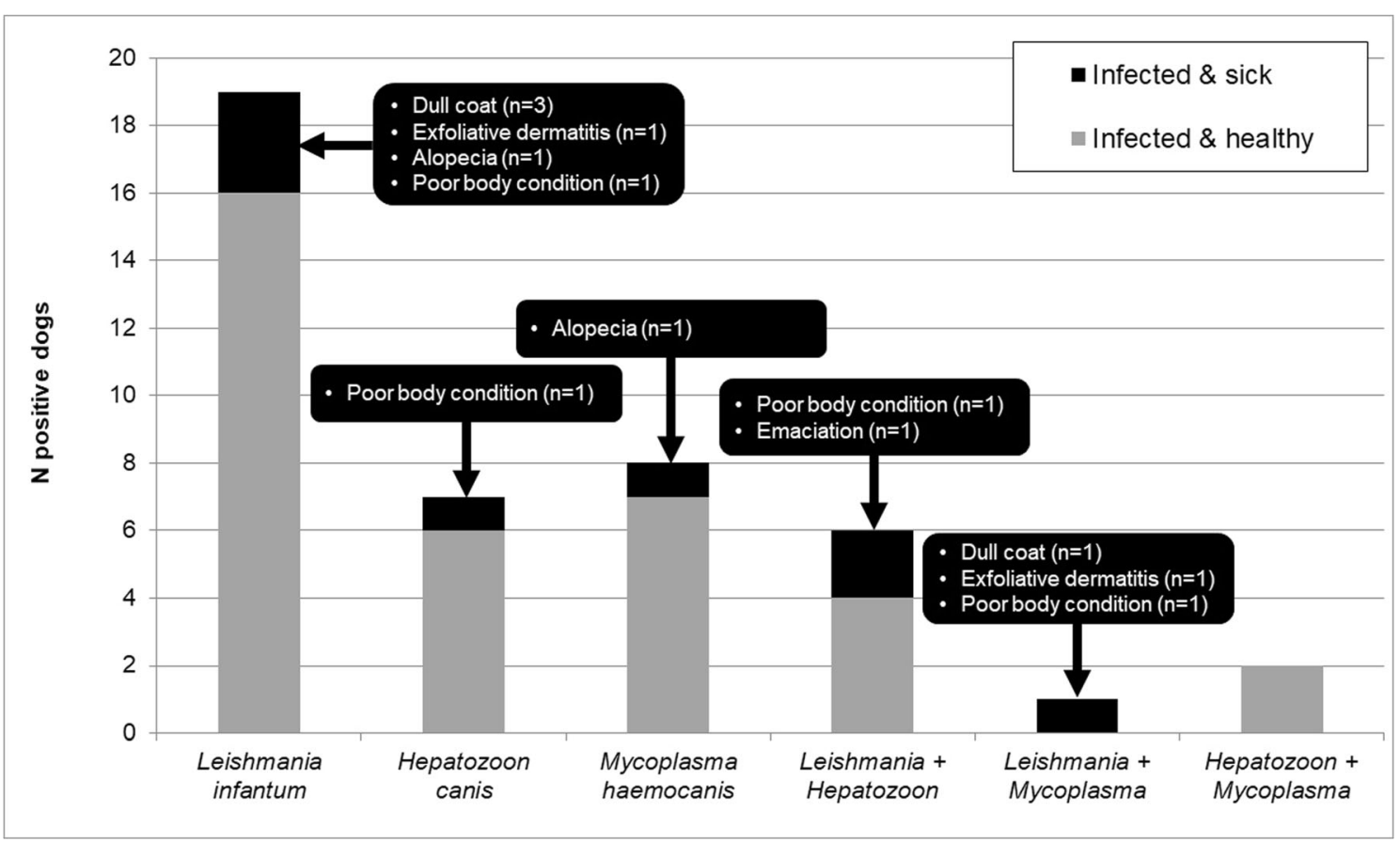

Fig. 2 Number of dogs positive for one or two pathogens and their clinical condition

aspirates (Reale et al. 1999). Moreover, dogs may also become PCR negative over time while specific antibodies persist for several months (Otranto et al. 2010). According to the data available from the late 1950s, phlebotomine sandflies, which are recognised vectors of Leishmania parasites, were nearly absent in Crete (Hadjinicolaou 1958), but they have reemerged with growing population density reported during the last 30 years (Christodoulou et al. 2012). This resulted in an increasing number of human cases reported. In particular, 66 cases of human visceral leishmaniasis and 19 cases of cutaneous leishmaniasis had been recorded on this island between 1986 and 2010 (Christodoulou et al. 2012). According to a previous study, $L$. infantum was the predominant species found in human patients in Greece, while L. tropica could be confirmed only in the island of Crete (Ntais et al. 2013). Serology used in dogs does not differentiate between these two species (Baneth et al. 2017). The re-emergence of sandfly-borne infections in the Mediterranean is of some concern (Moriconi et al. 2017), and dogs play a pivotal role as reservoirs for zoonotic Leishmania species (Miró and López-Vélez 2018).

The prevalence rates of $H$. canis $(14.6 \%)$ and M. haemocanis (10.7\%) in the examined dogs from Crete were notably higher than those observed in studies from continental Greece $(0.7 \%$ and $5.6 \%$, respectively; Jensen et al. 2003; Tennant et al. 2011). Almost all of the dogs from this study were infected with the same $H$. canis genotype previously reported in cats (Baneth et al. 2013) and foxes (CriadoFornelio et al. 2006). This finding indirectly suggests the occurrence of common transmission pathways between domestic and wild animals on the island. In contrast to many other CVBD-causing pathogens, hemotropic mycoplasmas are known to be transmitted not only by blood-sucking arthropods, but also directly via infected blood (Willi et al. 2010). Concomitant infections and immunosuppression presumably induce acute onset of disease (Baneth et al. 2001; do Nascimento et al. 2012) or exacerbation of clinical symptoms (Morgado et al. 2016). The zoonotic potential of other hemotropic mycoplasmas has been demonstrated in several human cases (Steer et al. 2011; Dos Santos et al. 2008; Yuan et al. 2009). According to a previous study, patients with extensive arthropod or animal contact, like veterinarians and veterinary technicians, are particularly at risk of infection (Maggi et al. 2013).

Neither tick-borne bacteria from the family Anaplasmataceae, i.e., Anaplasma phagocytophilum, Anaplasma platys, Candidatus Neoehrlichia mikurensis, or Ehrlichia canis, nor Babesia vogeli was detected in the present study, which is quite surprising as the vector tick species Ixodes ricinus and Rhipicephalus sanguineus, responsible for the respective transmission, are known to occur on the island (Chochlakis et al. 2009; Dimanopoulou et al. 2017). This might be either due to the small sample size tested or to a low capacity of local $R h$. sanguineus lineages to transmit A. platys or E. canis (MoraesFilho et al. 2015; Diakou et al. 2018). Filarioid nematodes, including Dirofilaria spp., could also not be confirmed by PCR or (for $D$. immitis) antigen testing. However, among 200 dogs tested on four Greek islands, only one case of an imported D. immitis infection was reported, indicating that endemic infections by these parasites are most likely absent in insular Greece (Diakou et al. 2018). 
Variations in the occurrence and prevalence of the tested pathogens compared to studies from continental parts of Greece may originate from the different climate conditions between northern and southern Greece and consequently differences in vector abundance. The fact that Crete is an island and the circulation of infected animals and vectors is limited may also explain the variable pathogen distribution and infection rates.

In the present study, 10 dogs showed clinical signs indicative of CVBD (alterations of the coat or skin or reduced/poor body condition), four of these were infected with one and three with two pathogens, and so overall clinical signs were observed in $16.3 \%$ of the 43 infected animals and $5.0 \%$ of the 60 uninfected dogs. Around $20 \%$ of the Leishmania- or Hepatozoon-positive dogs and three out of nine double-positive animals were clinically affected. Although the study population was too small to draw definitive conclusions, a trend for the development of clinical disease was seen in dogs infected with several (two) pathogens compared to one and the odds for uninfected dogs to show clinical signs were the lowest.

In conclusion, our study demonstrated that several blood-associated pathogens, including those of veterinary and public health importance, circulate among the dog population in Crete. Furthermore, we also reported the first occurrence of $H$. canis and M. haemocanis on this island. Results herein presented are of a great importance for the local veterinarians who seemed largely unaware of these canine pathogens. Our findings could possibly improve the way of routine examinations and prophylactic treatment in this region, especially in the light of a high rate of clinically unaffected infected dogs that may act as pathogen carriers. Along this line, dissemination of infectious agents (including CVBD) to non-endemic countries (and, in the worst case, long-term establishment) is considered a significant animal and public health threat promoted by travelling pets and the - often illegal- transfer of animals from the Mediterranean areas to Central Europe (Jensen et al. 2003; Menn et al. 2010; Fooks and Johnson 2015; Cito et al. 2016; Rijks et al. 2016). Precise knowledge on the distribution of CVBD significantly supports measures for prevention of their spread.

Acknowledgements We are grateful to the employees of the shelters involved in this study for the on-site assistance, as well to those from the Animal Medical Center Ierapetra for establishing contact with the dog shelters and providing the laboratory facilities. We would also like to thank Tierklinik Hainburg (Austria) for supplying the quick tests.

Funding Information Open access funding provided by University of Veterinary Medicine Vienna.

\section{Compliance with ethical standards}

All sampling procedures were routinely performed by veterinarians on study sites, and the work was approved by local authorities. No further ethic permissions were required as no additional samples (besides the ones for routine health inspection of incoming animals) were taken for this study and the supervising veterinarian (NP) participated in the study.

Conflict of interest The authors declare that they have no conflicts of interest.

Open Access This article is distributed under the terms of the Creative Commons Attribution 4.0 International License (http:// creativecommons.org/licenses/by/4.0/), which permits unrestricted use, distribution, and reproduction in any medium, provided you give appropriate credit to the original author(s) and the source, provide a link to the Creative Commons license, and indicate if changes were made.

\section{References}

Baneth G, Samish M, Alekseev E, Aroch I, Shkap V (2001) Transmission of Hepatozoon canis to dogs by naturally-fed or percutaneouslyinjected Rhipicephalus sanguineus ticks. J Parasitol 87(3):606-611

Baneth G, Sheiner A, Eyal O, Hahn S, Beaufils JP, Anug Y, Talmi-Frank D (2013) Redescription of Hepatozoon felis (Apicomplexa: Hepatozoidae) based on phylogenetic analysis, tissue and blood form morphology, and possible transplacental transmission. Parasit Vectors 6:102. https://doi.org/10.1186/1756-3305-6-102

Baneth G, Yasur-Landau D, Gilad M, Nachum-Biala Y (2017) Canine leishmaniosis caused by Leishmania major and Leishmania tropica: comparative findings and serology. Parasit Vectors 10(1):113. https://doi.org/10.1186/s13071-017-2050-7

Brown GK, Martin AR, Roberts TK, Aitken RJ (2001) Detection of of Ehrlichia platys in dogs in Australia. Aust Vet J 79:554-558

Chochlakis D, Psaroulaki A, Kokkini S, Kostanatis S, Arkalati E, Karagrannaki E, Tsiatis K, Tselentis Y, Gikas A (2009) First evidence of Anaplasma infection in Crete, Greece. Report of six human cases. Clin Microbiol Infect 15(Suppl 2):8-9. https://doi.org/10. 1111/j.1469-0691.2008.02695.x

Christodoulou V, Antoniou M, Ntais P, Messaritakis I, Ivovic V, Dedet JP, Pratlong F, Dvorak V, Tselentis Y (2012) Re-emergence of visceral and cutaneous leishmaniasis in the Greek Island of Crete. Vector Borne Zoonotic Dis 12(3):214-222

Cito F, Rijks J, Rantsios AT, Cunningham AA, Baneth G, Guardabassi L6, Kuiken T, Giovannini A (2016) Prioritization of companion animal transmissible diseases for policy intervention in Europe. $\mathrm{J}$ Comp Pathol 155(Suppl. 1):S18-S26. https://doi.org/10.1016/j. jcpa.2015.01.007

Criado-Fornelio A, Martinez-Marcos A, Buling-Saraña A, BarbaCarretero JC (2003) Presence of Mycoplasma haemofelis, Mycoplasma haemominutum and piroplasmids in cats from southern Europe: a molecular study. Vet Microbiol 93(4):307-317

Criado-Fornelio A, Ruas JL, Casado N, Farias NA, Soares MP, Müller G, Brumt JG, Berne ME, Buling-Saraña A, Barba-Carretero JC (2006) New molecular data on mammalian Hepatozoon species (Apicomplexa: Adeleorina) from Brazil and Spain. J Parasitol 92(1):93-99. https://doi.org/10.1645/GE-464R.1

Diakou A, Di Cesare A, Morelli S, Colombo M, Halos L, Simonato G, Tamvakis A, Beugnet B, Paoletti P, Traversa D (2018) Endoparasites and vector-borne pathogens in dogs from Greek islands: pathogen distribution and zoonotic implications. BioRxiv (in press). Available online at: https://www.biorxiv.org/content/ early/2018/11/16/472365. Accessed 28 Dec 202018

Dimanopoulou AP, Starras AG, Diakou A, Lefkaditis M, Giadinis ND (2017) Prevalence of tick species in sheep and goat flocks in areas of 
southern Greece. J Hellenic Vet Med Soc 68(2):205-210. https://doi. org/10.12681/jhvms. 15606

do Nascimento NC, Santos AP, Guimaraes AM, Sanmiguel PJ, Messick JB (2012) Mycoplasma haemocanis - the canine hemoplasma and its feline counterpart in the genomic era. Vet Res 43:66. https://doi.org/ 10.1186/1297-9716-43-66

Dos Santos AP, Dos Santos RP, Biondo AW, Dora JM, Goldani LZ, De Oliveira ST, De Sá Guimarães AM, Timenetsky J, de Morais HA, González FH, Messick JB (2008) Hemoplasma infection in HIVpositive patient, Brazil. Emerg Infect Dis 14:1922-1924. https://doi. org/10.3201/eid1412.080964

Dujardin JC, Campino L, Cañavate C, Dedet JP, Gradoni L, Soteriadou K, Mazeris A, Ozbel Y, Boelaert M (2008) Spread of vector-borne diseases and neglect of leishmaniasis, Europe. Emerg Infect Dis 14(7):1013-1018. https://doi.org/10.3201/eid1407.071589

Fooks AR, Johnson N (2015) Jet set pets: examining the zoonosis risk in animal import and travel across the European Union. Vet Med (Auckl) 6:17-25. https://doi.org/10.2147/VMRR.S62059

Hadjinicolaou J (1958) Present status of Phlebotomus in certain areas of Greece. Bull World Health Organ 19(6):967-979

Hall TA (1999) BioEdit: a user-friendly biological sequence alignment editor and analysis program for Windows 95/98/NT. Nucleic Acids Symp Ser 41:95-98

Hide M, Bañuls AL (2006) Species-specific PCR assay for $L$. infantum/ L. donovani discrimination. Acta Trop 100(3):241-245. https://doi. org/10.1016/j.actatropica.2006.10.012

Hodžić A, Alić A, Fuehrer H-P, Harl J, Wille-Piazzai W, Duscher G (2015) A molecular survey of vector-borne pathogens in red foxes (Vulpes vulpes) from Bosnia and Herzegovina. Parasit Vectors 8:88. https://doi.org/10.1186/s13071-015-0692-x

Jensen J, Müller E, Daugschies A (2003) Für die Reisetiermedizin bedeutungsvolle arthropodenübertragene Infektionen bei Hunden in Griechenland. Prakt Tierarzt 84:430-438

le Fichoux Y, Quaranta JF, Aufeuvre JP, Lelievre A, Marty P, Suffia I, Rousseau D, Kubar J (1999) Occurrence of Leishmania infantum parasitemia in asymptomatic blood donors living in an area of endemicity in southern France. J Clin Microbiol 37:1953-1957

Maggi RG, Compton SM, Trull CL, Mascarelli PE, Mozayeni BR, Breitschwerdt EB (2013) Infection with hemotropic Mycoplasma species in patients with or without extensive arthropod or animal contact. J Clin Microbiol 51(10):3237-3241

Menn B, Lorentz S, Naucke TJ (2010) Imported and travelling dogs as carriers of canine vector-borne pathogens in Germany. Parasit Vectors 3:34

Miró G, López-Vélez R (2018) Clinical management of canine leishmaniosis versus human leishmaniasis due to Leishmania infantum: putting "One Health" principles into practice. Vet Parasitol 254:151-159. https://doi.org/10.1016/j.vetpar.2018.03.002

Miró G, Montoya A, Roura X, Galvez R, Sainz A (2013) Seropositivity rates for agents of canine vector-borne diseases in Spain: a multicentre study. Parasit Vectors 6:117. https://doi.org/10.1186/ 1756-3305-6-117

Moraes-Filho J, Krawczak FS, Costa FB, Soares JF, Labruna MB (2015) Comparative evaluation of the vector competence of four South American populations of the Rhipicephalus sanguineus group for the bacterium Ehrlichia canis, the agent of canine monocytic ehrlichiosis. PLoS One 10(9):e0139386. https://doi.org/10.1371/ journal.pone. 0139386

Morgado FN, Cavalcanti AD, Miranda LH, O'Dwyer LH, Silva MR, Menezes RC, Andrade da Silva AV, Boité MC, Cupolillo E, Porrozzi R (2016) Hepatozoon canis and Leishmania spp. coinfection in dogs diagnosed with visceral leishmaniasis. Rev Bras
Parasitol Vet 25(4):450-458. https://doi.org/10.1590/S198429612016065

Moriconi M, Rugna G, Calzolari M, Bellini R, Albieri A, Angelini P, Cagarelli R, Landini MP, Charrel RN, Varani S (2017) Phlebotomine sand fly-borne pathogens in the Mediterranean Basin: human leishmaniasis and phlebovirus infections. PLoS Negl Trop Dis 11(8):e0005660. https://doi.org/10.1371/journal. pntd.0005660

Ntais P, Sifaki-Pistola D, Christodoulou V, Messaritakis I, Pratlong F, Poupalos G, Antoniou M (2013) Leishmaniases in Greece. Am J Trop Med Hyg 89(5):906-915. https://doi.org/10.4269/ajtmh.13-0070

Otranto D, Dantas-Torres F, Breitschwerdt EB (2009) Managing canine vector-borne diseases of zoonotic concern: part one. Trends Parasitol 25(4):157-163. https://doi.org/10.1016/j.pt.2009.01.003

Otranto D, Testini G, Dantas-Torres F, Latrofa MS, Diniz PP, de Caprariis D, Lia RP, Mencke N, Stanneck D, Capelli G, Breitschwerdt EB (2010) Diagnosis of canine vector-borne diseases in young dogs: a longitudinal study. J Clin Microbiol 48(9):3316-3324. https://doi. org/10.1128/JCM.00379-10

Reale S, Maxia L, Vitale F, Glorioso NS, Caracappa S, Vesco G (1999) Detection of Leishmania infantum in dogs by PCR with lymph node aspirates and blood. J Clin Microbiol 37(9):2931-2935

Rijks JM, Cito F, Cunningham AA, Rantsios AT, Giovannini A (2016) Disease risk assessments involving companion animals: an overview for 15 selected pathogens taking a European perspective. J Comp Pathol 155(Suppl 1):S75-S97. https://doi.org/10.1016/j. jcpa.2015.08.003

Spanakos G, Patsoula E, Kremastinou T, Saroglou G, Vakalis N (2002) Development of a PCR-based method for diagnosis of Leishmania in blood samples. Mol Cell Probes 16(6):415-420

Steer JA, Tasker S, Barker EN, Jensen J, Mitchell J, Stocki T, Chalker VJ, Hamon M (2011) A novel hemotropic Mycoplasma (hemoplasma a) in a patient with hemolytic anemia and pyrexia. Clin Infect Dis 53(11):e147-e151. https://doi.org/10.1093/cid/cir666

Tennant KV, Barker EN, Polizopoulou Z, Helps CR, Tasker S (2011) Real-time quantitative polymerase chain reaction detection of haemoplasmas in healthy and unhealthy dogs from Central Macedonia, Greece. J Small Anim Pract 52(12):645-649. https:// doi.org/10.1111/j.1748-5827.2011.01126.x

Willi N, Novacco M, Meli ML, Wolf-Jäckel GA, Boretti FS, Wengi N, Lutz H, Hofmann-Lehmann R (2010) Haemotrope Mykoplasmen bei Hund und Katze: Übertragung, Diagnose, Prävalenz und Bedeutung in Europa. Schweiz Arch Tierheilkd 152:237-244. https://doi.org/10.1024/0036-7281/a000055

Yuan CL, Liang AB, Yao CB, Yang ZB, Zhu JG, Cui L, Yu F, Zhu NY, Yang XW, Hua XG (2009) Prevalence of Mycoplasma suis (Eperythrozoon suis) infection in swine and swine-farm workers in Shanghai, China. Am J Vet Res 70:890-894. https://doi.org/10. 2460/ajvr.70.7.890

Zintl A, Finnerty EJ, Murphy TM, de Waal T, Gray JS (2011) Babesias of red deer (Cervus elaphus) in Ireland. Vet Res 42:7. https://doi.org/ $10.1186 / 1297-9716-42-7$

Publisher's note Springer Nature remains neutral with regard to jurisdictional claims in published maps and institutional affiliations. 